\title{
The impact of product quality and service quality on consumer loyalty (a case study of Bandeng Rozal in Bandengan village, Kendal district, Kendal regency)
}

\author{
Mawadah Murtiawati ${ }^{1}$, Zuhdan Ady Fataron² \\ 1,2Universitas Islam Negeri Walisongo, Semarang, Indonesia
}

\begin{abstract}
Purpose-The purpose of this research is to test quality of products and quality of service to consumer loyalty of small business, Bandeng Rozal.

Method - Data were obtained from distributing questionnaires to 100 consumers using simple random sampling and measured by the scale of Likert. Quantitative analysis included validity and reliability test, classic assumption test, multiple linear regression analysis, hypothesis testing through T-test and $F$ test, and analysis of the coefficient of determination $\left(R^{2}\right)$, while data processing is run used SPSS 16.

Result-The result showed the variables in this research had a significant effect on consumer loyalty. Based on the F test, it showed that variables in this study in which they were product quality and service quality simultaneously or jointly have a significant effect on consumer loyalty.

Implication - This result can assist small business in increasing their consumer loyalty.

Originality - This research focuses on small business adaptability in competing in the industry with a marketing perspective.
\end{abstract}

Keywords: product quality; service quality; customer loyalty

\footnotetext{
${ }^{2}$ Author correspondence: Zuhdan Ady Fataron, zuhdan_ady_fataron@walisongo.ac.id, Universitas Islam Negeri Walisongo, Jl. Walisongo No.3-5, Ngaliyan, Semarang, Indonesia
} 


\section{Introduction}

In this globalization era, there are many business competitions in a form of small businesses (UKM), so it must be faced with well-done arrangement JIEMB | 100 from various factors of production owned by the company. Marketers who will sell their products in form of good and service must fulfill what is needed and desired by their consumers, so they can provide a better value than their competitors. Marketers must try to influence consumers in all ways so that consumers are willing to buy the product which is offered, even they originally don't desire it, they become interest to buy it.

Kendal Regency is known as an abundant supply of milkfish, therefore many people in Kendal Regency exploit these natural products by processed production activities made from milkfish. One of them is UKM Bandeng Rozal which is a variety of industries that take advantage with basic material of milkfish and well-known in Bandengan Village, Kendal District, Kendal Regency. The products that are made of milkfish are marketed to almost of the traditional markets in Kendal Regency and their own shop located in Bandengan Village, Kendal District. The products have a good quality and are able to compete in the market.

Based on the data in Table 1, the sales volume of milkfish Rozal from 2016 to 2017 experienced a significant increase in the amount of Rp. 35,700,000, from $\operatorname{Rp~1,140,350,000~to~} \operatorname{Rp~1,140.50,000.~Then~from~} 2017$ to 2018, it will decrease in the amount of Rp. 8,653,000, from Rp. 1,140,050,000 to Rp.1,131,397,000.

In addition to UKM Bandeng Rozal in Kendal District, there are more than 10 competitors who make products from milkfish. It causes sales decrease of UKM Bandeng Rozal. Companies that want their business to go forward and

Table 1. Milkfish sales data

\begin{tabular}{ccc}
\hline SB & Year & Sales Amount (Rp) \\
\hline 1 & 2016 & Rp 1.104.350.000,- \\
2 & 2017 & Rp 1.140.050.000,- \\
3 & 2018 & Rp.1.131.397.000,- \\
\hline
\end{tabular}


win the competition must be able to compete, so that the number of sales increases and can survive. In order to win business competition, retain customers and seize a floating market, the company is required to have ability to adapt its business strategy and a constantly changing environment.

With the problem of the many business competition that arises and decrease in the amount of milkfish sales, so the management system that must be used by entrepreneurs is prioritisation of product quality to be able to compete in the market and increase the number of sales. Based on this, the researcher take the product quality variable as the first independent variable (X1).

For companies, quality of service is adjustment with specifications demanded by consumers. With the good quality of service within the company, it will create satisfaction for its customers. After the customer is satisfied with the product which he receives, the customer will compare the services provided. If customers feel really satisfied, they will buy back and recommend to others to buy in the same place. Based on this, the researcher takes the service variable as the second independent variable (X2).

Therefore, to make a purchase based on the needs and desires of the quality of the products offered and the quality of services provided to consumers is one of the important things, experience of consumers when they hold purchase process will determine loyalty of consumers to make a repurchase or not. Based on this, the researcher takes the consumer loyalty variable as the dependent variable $(Y)$.

Based on the explanation above, the problems that can be formulated in this study are whether the quality of the product has a significant effect on consumer loyalty in UKM Bandeng Rozal, whether the quality of service has a significant effect on consumer loyalty in UKM Bandeng Rozaland whether the product quality and service quality simultaneously have a significant effect to consumer loyalty on UKM Bandeng Rozal. 


\section{Literature Review}

\section{The product quality}

JIEMB | 102

According to Kotler, quality is totality of features and characteristic that affords products to satisfy stated or unstated needs. The quality of a product can be assessed and based on a number of different criteria, because of different interests and involvement of consumers. Perception of quality reflects overall feeling of consumers about a product. In an Islamic perspective, quality is a concept in totality. The concept is not only related to human relations but also between humans and Allah SWT.

According to Kotler and Armstrong in Rahcma (2014), They define that a product is anything that can be offered to market to get attention, bought, used or consumed, in which it can satisfy desires or needs. Meanwhile, according to Supranto and Nandan Limakrisna (2010), product is what is needed and desired by a consumer to fulfill perceived needs. The quality of the product according to Kotler (in Rachma, 2014) is overall characteristics of a product or service on the ability to satisfy the stated or implied needs.

If the company wants to maintain its competitive excellence, it is necessary to consider indicators of product quality. Business practices that prioritize quality as business competitiveness don't contradict Islamic teachings, because the essence of improving the quality of products and services to be better is part of honesty and truthfulness in business. So it creates sincerity for each of them in doing business transactions between seller and buyer. improving the quality means also steps to fulfill the desires of customers and consumers.

As for to determine the dimensions of product quality, according to David Garvin, it can go through eight indicators as follows (Eko Purnomo, 2016):

1. Dimension of performance or product performance. Performance is the main characteristic or function of a product.

2. Dimension of features or product features. Feature is additional characteristic or feature that completes the basic benefits of a product. 
3. Dimension Reliability or product reliability. Reliability is chance of a product free from failure when carrying out its function.

4. Dimension Conformance or suitability. It relates to the level of conformity with specification that has been set previously based on customer desires.

5. Dimension of Durability or durability. Durability indicates the age of the product. It is the amount of use of a product, before the product is replaced or damaged. The longer the durability is, the more durable is.

6. Aesthetic dimension or beauty of the product appearance. The beauty involves the appearance of the product that makes consumers joy. It is often done in the form of product design or packaging.

7. Dimension of perceived quality. The last dimension is perceived quality. It concerns the consumer's assessment of the image, brand, or advertisement. Famous branded products are usually perceived to be higher quality than brands that are not heard. That is why the product is always trying to build its brand, so it has high brand equity.

\section{Service quality}

Service is an activity that has several intangible elements related to it, involves some interaction with consumers or property in ownership and doesn't result in transfer of ownership (Andrian Payne, 2010).

Service quality is seen as one component that needs to be realized by the company. Because it has the influence to bring in new customers and can reduce the possibility of old customers to move to other companies.

According to Tjiptono, 2007, service quality can be known by comparing consumers' perception of the services which they actually receive. With the services, they actually expect or want to the service attributes of a company.

Islam teaches that if you want to provide good business results in the form of goods or services, you should provide quality, don't give bad quality to others. As Qur'an explains it in surah Al-Baqarah (2) verse 267: 
"O you who have believed, spend from the good things which you have earned and from that which We have produced for you from the earth. And do not aim toward the defective therefrom, spending [from that] while you would not take it (yourself) except with closed eyes. And know that Allah is Free of need and Praiseworthy."

In an effort to maintain a good service commitment and to improve the quality of service quality, a company must measure the performance of service quality to afford creating satisfaction for consumers. Service quality assesment can be seen from all dimensions that exist in the its service. Quality of service is determined by several indicators, they are:

1. Tangible is ability of a company to show its existence to external parties.

2. Reability is company's ability to provide service, such as company accurately and reliably promises it.

3. Responsiviness is a policy to help and provide fast and appropriate service for customers by delivering information.

4. Emphaty is something to give sincere and individual attention or personal attention given to customers by trying to understand consumer desires.

\section{Consumer loyalty}

Loyalty in Islam is called al-wala '. Etymologically, Alwala 'has several meanings, including love, helping, following, and getting close to something. The concept of loyalty in Islam or al-wala' is an absolute submission to Allah SWT in the form practicing completely Islamic sharia. Customer loyalty in Islam occurs when the activities of muamalah can mutually provide benefits for both parties. Because the fulfillment of their obligations and rights is through application of Islamic values (Fitria, 2015).

Consumer loyalty is a formation of attitudes and behavior patterns of a consumer toward a purchase and using product result from their previous experience (Philip Kotler, 2000). 
Attitude of consumer loyalty is formed after customer satisfaction is fulfilled. Based on previous research, consumer loyalty is measured by 3 indicators, they are (Evetri Juliana Tamba, 2017):

1. Repeat, is if the consumer or customer needs goods or services provided by relevant goods or service provider.

2. Retention, it is not affected by goods or services offered by other parties.

3. Referral, is when the goods or services received are satisfactory. Then consumer will notify to others, whereas if there is dissatisfaction with the service which is received. He will not talk to others, but he will instead inform the less satisfied service to the provider of the goods.

\section{Effect of product quality on consumer loyalty}

In an Islamic perspective, quality is a concept in totality. The concept is not only related to human relations but also between humans and Allah SWT. Thus product quality is very important to increase consumer loyalty, where consumers will choose products with good quality to compare with low quality (Putri, 2014). Product quality is very influential on customer loyalty if the product quality is good, customer loyalty will increase. Based on the explanation, the hypothesis which is tested is:

H1: Product quality has a significant effect on consumer loyalty

\section{Effect of service quality on consumer loyalty}

Another factor that influenced consumer loyalty is service quality. According to Tjiptono (2007), service quality can be known by comparing consumers' perceptions of the actual services which they receive or obtain with the services and actually expect from a company's services. Islam teaches that if you want to provide good business results in the form of goods or services, you should provide quality, don't give bad or not quality to others.There is Effort to maintain a good service commitment and to improve the quality of service quality, then a company must measure the performance of service quality is able to create satisfaction for consumers. Based on the explanation, the hypothesis to be tested is: 
H2: Service quality has significant impact on consumer loyalty

\section{Effect of product quality and service quality simultaneously affect consumer loyalty}

According to Philip Kotler (2000), consumer loyalty is the formation of attitudes and behavior patterns of a consumer toward the purchase and use of products resulted from their previous experiences. Customer loyalty in Islam occurs when the muamalah activity can provide benefits that are mutually beneficial to both sides. Because the fulfillment of their obligations and rights are through the application of Islamic values (Fitria, 2015). Factors that influence consumer loyalty, according to Dharmamesta, are product quality and promotion. Consumers who get satisfaction with the product which they buy. They tend to repurchase the same product (Laili, 2013). Even though it has good product quality, it does not necessarily make consumers pus. Consumer satisfaction also depends on the quality of service provided (Maria, 2013). Marketers who have little or no attention to the quality of the products offered and the quality of services provided will bear the risk of customer loyalty. Based on the explanation, the hypothesis which is tested is:

H3: Product quality and service quality simultaneously have a significant effect on consumer loyalty.

\section{Research methods}

This research is a field study (field study research) which is direct observation to the object researched in order to obtain relevant data (Sugiyono, 2008). In the implementation of this research, the authors use a quantitative descriptive approach that is research by emphasizing its analysis on numerical data (numbers) that are processed by statistical methods. They are namely quantitative data collected through measurement (Anwar, 1999).

Data sources in research are data which are directly obtained from the first data source at this research location or research object. Primary data were obtained directly from distribution of questionnaires to consumers of UKM Bandeng Rozal. Furthermore, The data were obtained from secondary sources 
of data needed and obtained from literature, journals, magazines, newspapers, etc. or data related to research (Bungin, 2005).

Population is an entire object or subject that is in an area and fulfills certain conditions related to the research problem or totality units or individuality within the scope to be examined (Martono, 2012). The population used as objects in this study are consumers of UKM Bandeng Rozal. Based on Solvin's formula, it was found that the number of samples used in the study were 100 respondents.

In this research, researcher used Method of Collecting Data in four ways, they are:

1. Interview, interview is a way to get information or data from respondents (interviewees) by asking direct questions (face to face) between the interviewer and the interviewee. In this research, the author directly conducted an interview with the owner of UKM Bandeng Rozal as one of the supporters who strengthened the data.

2. Questionnaire; questionnaire is a list of questions distributed by post to be filled and returned or can also be answered under control of the researcher. The research questionnaire was distributed to consumers who were purchasing products from the UKM Bandeng Rozal. In this research, data processing system is carried out by using a Likert scale, in 5 points scale with the same interval.

3. Observation technique; observation technique requires a observation from a researcher either directly or indirectly to those research using instrument of research guideline in observation sheets or others.

4. Documentation method; the method of collecting data is through books, journals, magazines, internet sites related to research which is done and become to support material reference for researcher.

Research variables and measurement variables in this research are as stated in Table 2. 
Mawadah Murtiawati \& Zuhdan Ady Fataron

Table 2. Research and measurement variables

\begin{tabular}{|c|c|c|c|}
\hline $\begin{array}{l}\text { Research } \\
\text { Variable }\end{array}$ & Definition & Indicator & Scale of Measurement \\
\hline $\begin{array}{l}\text { Product } \\
\text { quality }(X 1)\end{array}$ & $\begin{array}{l}\text { According to Kotler, product } \\
\text { quality is totality characteristic of } \\
\text { a product or service of ability to } \\
\text { satisfy needs that are expressed } \\
\text { or implied }\end{array}$ & $\begin{array}{l}\text { Performance } \\
\text { Features } \\
\text { Reability } \\
\text { Compliance of } \\
\text { specification } \\
\text { (conformance) } \\
\text { Durability } \\
\text { Servicibility } \\
\text { Aesthetics } \\
\text { Perceived quality } \\
\text { (Eko Purnomo: 2016) }\end{array}$ & $\begin{array}{l}\text { Measured through a } \\
\text { questionnaire using a } \\
\text { Likert scale }\end{array}$ \\
\hline $\begin{array}{l}\text { Service } \\
\text { quality (X2) }\end{array}$ & $\begin{array}{l}\text { Quality of service is a } \\
\text { measurement of how much the } \\
\text { level of service that is provided is } \\
\text { able to match customer } \\
\text { expectation. }\end{array}$ & $\begin{array}{l}\text { Tenable } \\
\text { Reability } \\
\text { Responsiveness } \\
\text { Enhaty } \\
\text { Assurance } \\
\text { (Monica Maria dan } \\
\text { Muhamad Yusak } \\
\text { Anshori: 2013) }\end{array}$ & $\begin{array}{l}\text { Measured through a } \\
\text { questionnaire using a } \\
\text { Likert scale }\end{array}$ \\
\hline $\begin{array}{l}\text { Consumer } \\
\text { loyalty }(Y)\end{array}$ & $\begin{array}{l}\text { Consumer loyalty is formation of } \\
\text { attitudes and behavior patterns } \\
\text { of a consumer toward purchase } \\
\text { and use of products resulted } \\
\text { from their previous experience. }\end{array}$ & $\begin{array}{l}\text { Repeat } \\
\text { Retention } \\
\text { Referral } \\
\text { (Evetri Juliana Tamba, } \\
\text { et al: 2017) }\end{array}$ & $\begin{array}{l}\text { Masured through a } \\
\text { questionnaire using a } \\
\text { Likert scale }\end{array}$ \\
\hline
\end{tabular}

\section{Results and discussion}

\section{Validity test}

Validity is a measurement that shows the level of validity from an instrument (Anoraga, 2008). Validity test is done by comparing the corrected item value - total correlation with $r$ table.

Based on Table 3, it can be known that the value of $r$ count from totality of questionnaire which is amount of 18 items is declared with valid. Because it has a value of $r$ count $>r$ table, so that it is at a significant level of 0.05 . Then it can be concluded that all research questions have a valid correlation. 
The impact of product quality and service ....

Table 3. Validity test results of research variable

\begin{tabular}{|c|c|c|c|c|c|}
\hline SN & Variable & Variable code & r count & r table & Criteria \\
\hline 1. & Product Quality (X1) & $\mathrm{X} 1.1$ & 0,424 & 0,196 & Valid \\
\hline 2. & & $X 1.2$ & 0,627 & 0,196 & Valid \\
\hline 3. & & $\mathrm{X} 1.3$ & 0,546 & 0,196 & Valid \\
\hline 4. & & $X 1.4$ & 0,387 & 0,196 & Valid \\
\hline 5. & & X1.5. & 0,521 & 0,196 & Valid \\
\hline 6. & & $X 1.6$ & 0,383 & 0,196 & Valid \\
\hline 7. & & $\mathrm{X} 1.7$ & 0,366 & 0,196 & Valid \\
\hline 8 & Service Quality (X2) & $X 2.1$ & 0,358 & 0,196 & Valid \\
\hline 9. & & $X 2.2$ & 0,402 & 0,196 & Valid \\
\hline 10. & & $X 2.3$ & 0,343 & 0,196 & Valid \\
\hline 11. & & $X 2.4$ & 0,425 & 0,196 & Valid \\
\hline 12. & & $X 2.5$ & 0,403 & 0,196 & Valid \\
\hline 13. & & $X 2.6$ & 0,401 & 0,196 & Valid \\
\hline 14. & & $X 2.7$ & 0,241 & 0,196 & Valid \\
\hline 15. & Consumer Loyalty $(\mathrm{Y})$ & $\mathrm{Y} 1$ & 0,451 & 0,196 & Valid \\
\hline 16. & & Y2 & 0,576 & 0,196 & Valid \\
\hline 17. & & Y3 & 0,412 & 0,196 & Valid \\
\hline 18. & & Y4 & 0,238 & 0,196 & Valid \\
\hline
\end{tabular}

\section{Reliability test}

Reliability test is used to measure the consistency of constructs or research variables. To test the reliability test is done by using the Crobach Alpha statistical test $(\alpha)$. A construct or variable is stated to be reliable, if it gives an Alpha coefficient which is greater than 0.60 or close to 1 .

Based on the results of the Table 4, it can be stated that all variables used in this study are reliable, because it has a Cronbach Alpha coefficient value greater than critical value of 0.6 .

Table 4. Result of reliability test

\begin{tabular}{llll}
\hline SN & Research Variable & Cronbach's Alpha & Explanation \\
\hline 1 & Product Quality & 0.663 & Reliable \\
2 & Senvice quality & 0.756 & Reliable \\
3 & Consumer Loyalty & 0.689 & Reliable \\
\hline
\end{tabular}

Journal of Islamic Economics, Management, and Business - Vol. 1 No. 1 (2019) 


\section{Classical assumption test}

Normality test

The normality test is anticipated to test if in the regression model JIEMB | 110 Dependent variable and Independent variable have normal distribution or not. Testing normality of the data uses Kolmogorov-Semirnov test of normality in SPSS. According to Singgih Santosa (2016: 393), decision taking can be done based on probabilities (asymptotic significant). If probability is more than 0.05 , the distribution of the population is normal.

Result of normality test in this research, from the calculation, is obtained Asymp value Sig (2-tailed) of $0.059>0.05$, then the data is normally distributed.

\section{Heteroscedasticity test}

Heteroscedasticity test is purposed to test if variance or residual inequality in a regression model occurs from one observation to another. A good regression model is homoscedasticity or does not produce heteroscedasticity.

From the result in Table 5, there is a significant value which is more than 0.05 , because the value of all independent variables is above 0.05 . So it can be concluded that heteroscedasticity in this regression model did not occur.

\section{Multicollinearity test}

Multicollinearity test is purposed to test if there is a correlation among independent variables. A good regression model is regression that does not have correlation among independent variables.

To detect presence or absence of multicollinearity is by looking at the value of tolerance and VIF. If tolerance value is smaller and VIF is greater, the

Table 5. Heteroscedasticity test result

\begin{tabular}{lll}
\hline Model & & Sig. \\
\hline 1 & (Constant) & .499 \\
& X1_Product Quality & .548 \\
& X2_Service Quality & .079 \\
\hline
\end{tabular}


Table 6. Multicollinearity Test Result

\begin{tabular}{llll}
\hline \multicolumn{2}{l}{ Model } & \multicolumn{2}{l}{ Clinearity Statistics } \\
\hline 1 (Constant) & Tolerance & VIF \\
\multicolumn{2}{c}{ X1_Product Quality } & & \\
X2_Service Quality & .876 & 1.142 \\
\hline
\end{tabular}

multicollinearity problem is more to occur. mentioned In most research, if tolerance is more than 0.1 and VIF less tahan 10, multicollinearity is no.

From Table 6, it can be seen that the tolerance value of the two independent variables of 0.876 is greater than 0.1 . And VIF of this number 1,142 is less than 10 . So it can be concluded that in the regression model there is no multicollinearity problem.

From Table 7, Durbin - Watson value was 2,245, this value wolud be compared with the table value using $5 \%$ significance value of the sample number 100 and the number of independent variables $2(k=2)$, then the value of $\mathrm{dL}=1.634$ and $\mathrm{dU}=1.715$ could be obtained.

From the SPSS calculation results, the Durbin Watson Count was obtained 2.245 , this number was greater than the du value of 1,715 , so that Ho was accepted and there was no autocorrelation.

\section{Multiple linear regression test}

Multiple linear regression analysis test was conducted to determine the influence extent of independent variables which are product quality and service quality on the dependent variable of customer loyalty. Result of mutiple linear regression analysis could be seen in Table 8.

Table 7. Autocorrelation Test Result

\begin{tabular}{llllll}
\hline \multirow{2}{*}{ Model } & $\mathrm{R}$ & R Square & $\begin{array}{l}\text { Model Summary } \\
\text { Adjusted R } \\
\text { Square }\end{array}$ & $\begin{array}{l}\text { Std. Error of the } \\
\text { Estimate }\end{array}$ & Durbin-Watson \\
\hline 1 & $.154^{\mathrm{a}}$ & .024 & .004 & .87135 & 2.245 \\
\hline
\end{tabular}


Mawadah Murtiawati \& Zuhdan Ady Fataron

Table 8. Multiple Linear Regression Test Result

\begin{tabular}{|c|c|c|c|c|c|c|}
\hline \multicolumn{7}{|c|}{ Coefficients $^{a}$} \\
\hline \multirow{3}{*}{ Model } & & \multirow{2}{*}{\multicolumn{2}{|c|}{$\begin{array}{l}\text { Unstandardized } \\
\text { Coefficients }\end{array}$}} & \multirow{3}{*}{$\begin{array}{l}\text { Standardized } \\
\text { Coefficients } \\
\text { Beta }\end{array}$} & \multirow{3}{*}{$\mathrm{T}$} & \multirow{3}{*}{ Sig. } \\
\hline & & & & & & \\
\hline & & B & Std. Error & & & \\
\hline \multirow{3}{*}{1} & (Constant) & 20.145 & 2.163 & & 9.315 & .000 \\
\hline & Product Quality & 4.096 & .033 & .022 & 2.514 & .003 \\
\hline & Service Quality & 3.218 & .024 & .031 & 3.287 & .002 \\
\hline
\end{tabular}

Based on the result of the analysis which had been done, the regression equation that was formed is as follows:

$$
\mathrm{Y}=20,145+4,096 \mathrm{X} 1+3,218 \mathrm{X} 2
$$

From the multiple linear regression equation above, it colud be interpreted and taken in the following decision:

1. A constant of 20.145 is determined if the independent variable's value is 0 (zero), then consumer loyalists in buying products at UKM Bandeng Rozal depend on the number 20.145 .

2. Product quality regression coefficient (X1) of 4,096 stated that if the product quality variable had increased by $1 \%$, consumer loyalty would rise by 4,096 . It can be concluded that the product quality variable influenced consumer loyalty in buying products at UKM Bandeng Rozal.

3. Service quality regression coefficient $(X 2)$ of 3.218 stated that if the service quality variable had increased by $1 \%$, consumer loyalty would increase by 3.218 . It could be concluded that the service quality variable influenced consumer loyalty in buying products at UKM Bandeng Rozal. T-test

The $t$ test was used to determine the influence significance of independent variables (product quality and service quality) in a partial or individual manner which explained the dependent variable (customer loyalty).

From the result of $t$ test in Table 9, the significance test of each variable is obtained as follows with $\mathrm{t}$ table $(1,661)$ : 
The impact of product quality and service ....

Table 9. T-Test Result

\begin{tabular}{lllllll}
\hline \multirow{2}{*}{ Model } & & \multicolumn{2}{c}{ Coefficients $^{\mathrm{a}}$} & & & \\
Unstandardized & \multicolumn{2}{l}{$\begin{array}{l}\text { Standardized } \\
\text { Coefficients }\end{array}$} & $\begin{array}{l}\text { Coefficients } \\
\text { Beta }\end{array}$ & T & Sig. \\
& & B & Std. Error & Beta & & \\
\hline \multirow{3}{*}{1} & (Constant) & 20.145 & 2.163 & & 9.315 & .000 \\
& Product Quality & 4.096 & .033 & .022 & 2.514 & .023 \\
& Senvice Quality & 3.218 & .024 & .031 & 3.287 & .042 \\
\hline
\end{tabular}

JIEMB | 113

1. T value on product quality variable was 2,514 with a significant level of 0.023 or $23 \%$. Because the $t$ value wasgreater than $t$ table $(2.514>1.661)$ and the significance value was $0.023<0.05, \mathrm{H} 0$ was rejected and $\mathrm{H} 1$ was accepted. Then the product quality variable had a significant effect on consumer loyalty by $23 \%$.

2. T value of variable service quality was 3,287 with a significant level of 0.042 or $42 \%$. Because the $t$ value was greater than $t$ table $(3.287>1.661)$ and the significance value was $0.042<0.05, \mathrm{H} 0$ was rejected and $\mathrm{H} 1$ was accepted. Then the service quality variable significantly influenced consumer loyalty by $42 \%$.

Determination coefficient test $\left(R^{2}\right)$

Coefficient of determination was used to measure how much the percentage change of dependent variable could be explained by change in independent variable. By knowing the value of determination coefficient, it could be explained the goodness of regression model in predicting dependent variable. The coefficient of determination is higher, the ability of independent variable is better in explaining the behavior of dependent variable.

Table 10. Determination coefficient test $\left(R^{2}\right)$

\begin{tabular}{lrrrr}
\hline \multicolumn{5}{c}{ Model Summary $^{\mathrm{b}}$} \\
\hline Model & $\mathrm{R}$ & $\mathrm{R}$ Square & Adjusted R Square & Std. Error of the Estimate \\
1 & $.154^{\mathrm{a}}$ & .054 & .064 & .031 \\
\hline
\end{tabular}


Based on Table 10, coefficient of determination had an $\mathrm{R}$ square of 0.054 . It meant that $54 \%$ of consumer loyalty $(Y)$ could be explained by independent variables which were product quality and service quality. While the rest $(100 \%$ - $54 \%=46 \%$ ) was explained by other variables outside, the model was not explained in this research.

F-test

F test was used to support presence or absence of influence of independent variables on completely dependent variable (together). The resuls of testing could be seen in Table 10.

Value of $\mathrm{F}$ Table was with significance $0.1 \mathrm{df1}$ (numerator) $=\mathrm{k}-1$ or $3-1$ $=2$, and df2 (denominator) $=\mathrm{n}-\mathrm{k}$ or $100-3=97$, then the $\mathrm{F}$ table was obtained as 3.09. Based on ANOVA test or $F$ test which could be seen in the table, an Fcount of 5.181 could be obtained with a significance level of 0.008 .

Because the probability was much smaller than 0.05 (0.008 was smaller than 0.05 ) and the F count was greater than the F table (5.181> 3.09), it could be stated that the independent variables including product quality (X1) and service quality (X2) simultaneously or jointly affected the consumer loyalty variable $(Y)$ which was significantly.

\section{Conclusion}

From the discussion above, it could be obtained with following conclusions:

1. Based on partial test result ( $t$ test), $t$ value calculated on product quality variable was greater than t table, that is 2.514> 1.661 and significance value was $0.023<0.05$, then $\mathrm{H} 0$ was rejected and $\mathrm{H} 1$ was accepted. Then it could

Table 11. Simultaneous test (F-test) result

\begin{tabular}{lllllll}
\hline \multicolumn{2}{c}{ Model } & \multicolumn{5}{c}{ ANOVA $^{\mathrm{b}}$} \\
\hline \multirow{4}{*}{1} & Regression & 1.793 & $\mathrm{df}$ & Mean Square & $\mathrm{F}$ & Sig. \\
\hline & Residual & 73.647 & 2 & .896 & 5.181 & $.008^{\mathrm{a}}$ \\
& Total & 75.440 & 97 & .759 & & \\
\hline
\end{tabular}


The impact of product quality and service ....

be concluded that product quality variable had a significant effect on customer loyalty of UKM Bandeng Rozal by $23 \%$.

2. Based on partial test result ( $t$ test), $t$ value calculated of service quality variable was greater than t table, that was 3.287> 1.661 and significance value was $0.042<0.05$, then $\mathrm{H} 0$ was rejected and $\mathrm{H} 1$ was accepted. Then it could be concluded that variable service quality had a significant effect on consumer loyalty of UKM Bandeng Rozal by $42 \%$.

3. Based on result of testing model (Test F) in Table 11, F value calculated was greater than $\mathrm{F}$ table that was 5.181> 3.09 and the probability wasa smaller than 0.05 which was 0.008 . Then it could be concluded that the variables of product quality and service quality simultaneously had a significant effect on consumer loyalty in UKM Bandeng Rozal.

\section{References}

Andanawari, Rachma Anindya. Pengaruh Harga, Lokasi, dan Kualitas Produk Terhadap Keputusan Pembelian. Universitas Diponegoro. 2014.

Arikunto, Suharsimi. Prosedur Penelitian Suatu Pendekatan Praktik. Jakarta: PT. Rineka Cipta. 2006.

Azwar, Syaifudin Metode Penelitian. Jakarta : Pustaka Pelajar. 1999.

Bungin, M. Burhan. Metodologi Penelitian Kuantitatif. Jakarta: Prenada Kencana Group. 2005.

Kotler dan Kevin Lane Keller. Manajemen Pemasaran. Jakarta: Erlangga. Edis.13. 2009.

Maria, Monica dan Mohamad Yusak Anshori. Pengaruh KualitasProduk dan Kualitas Layanan Terhadap Keputusan Konsumen (Studi Kasus Pada Ayam Penyet Surabaya Jl. Dr. Mansyur Medan). Tahun 6 No. 1. 2013.

Martono, Nanang. Metode Penelitian Kuantitatif: Analisis Isi dan Analisis Data Sekunder. Jakarta: Rajawali Pers. cet.3. 2012.

Moureen, Margaretha. Studi Mengenai Loyalitas Pelanggan pada Divisi Asuransi Kumpulan AJB Bumi Putera. 
Payne, Andrian. Kebijakan Pemasaran. Jakarta: Bumi Aksara. 2010.

Priyatno, Duwi .Paham Analisis Statistik Data dengan SPSS Yogyakarta: MediaKom, 2010.

Prasetyo, Bambang dan Lina Mifatahul Jannah, Metode Penelitian Kuantitatif: Teori dan Aplikiasi, Jakarta: Raja Grafindo Persada. 2012

Purnomo, Eko. Pengaruh Harga Kualitas Produk dan Lokasi Terhadap Minat Beli Konsumen dalam Membeli Beras Lokal (Studi Kasus Desa Rambah Utama). 2016.

Salma, Fitria Salahika. Pengaruh Kualitas Jasa Prespektif Islam Terhadap Kepuasan dan Loyalitas Pelanggan Hotel Grand Kalimas di Surabaya. Vol. 2 No. 4. Universitas Airlangga. 2015.

Siregar, Syofian. Metode Penelitian Kuantitatif: DilengkapiPerbandingan Perhitungan Manual \& SPSS Edisi Pertama. Jakarta:Prenadamedia Group. 2015

Sugiyono, Metode Penelitian Pendidikan; Pendekatan Kuantitatif, Kualitatif dan R \& D, Bandung: Alfabeta. 2010.

Sugiyono. Metode Penelitian Bisnis. Bandung: Alfabeta. 2008.

Supranto dan Nandan Limakrisna. Perilaku Konsumen dan Strategi Pemasaran Untuk Memenangkan Persaingan. Jakarta: Mitra Wacana Media. 2010.

Soewadji, Yusuf. Pengantar Metodologi Penelitian. Jakarta: Mitra Wacana Media. 2012.

Tamba, Evetri Juliana dkk.. Pengaruh Kualitas Pelayanan Terhadap Loyalitas Konsumen pada Shine Holiday PT. Sinar. 2017.

Tjiptono, Fandy. Strategi Pemasaran. Jogyakarta: Andi Ofset. Edisi Pertama. 2007.

Hasil Wawancara dengan Bapak Rozikin selaku pemilik UKM Bandeng Rozal Tanggal 11 Maret 2019

Al- Quran dan terjemah

Hasil Wawancara dengan Bapak Rozikin selaku pemilik UKM Bandeng Rozal Tanggal 14 September 2018 jam 16.00 WIB.

https://www.hukumonline.com/pusatdata/detail/842/node/258/keputusanpresiden-nomor-99-tahun-1998 diakses pada 19 Oktober 2018. 
The impact of product quality and service ....

Arifni, Umi. 2015, "The Effect of Islamic Good Corporate Governance on Profit Sharing Financing through Sharia Compliance", Accounting Analysis Journal, 1-12. (Segoe UI, 10,5)

Matthew J. Kotchen dan Jon Jungbien Moon, "Corporate Social Responsibility for Irresponsibility"NBER Working Paper No. w17254. (July 2011). 
Mawadah Murtiawati \& Zuhdan Ady Fataron

\section{JIEMB | 118}

Journal of Islamic Economics, Management, and Business - Vol. 1 No. 1 (2019) 